\title{
PERLINDUNGAN HUKUM SINEMATOGRAFI TERHADAP PENGAKSESAN TANPA HAK OLEH PENGGUNA APLIKASI TELEGRAM BERDASARKAN UNDANG-UNDANG HAK CIPTA DAN UNDANG-UNDANG INFORMASI DAN TRANSAKSI ELEKTRONIK DI INDONESIA
}

\author{
${ }^{1}$ Kemala Megahayati, ${ }^{2}$ Muhamad Amirulloh, ${ }^{3}$ Helitha Novianty Muchtar \\ Fakultas Hukum, Universitas Padjadjaran, Bandung, Jawa Barat. \\ Correspondent email : kemalamegahayati@gmail.com
}

\begin{tabular}{|c|c|}
\hline Article History & \\
\hline Submission & 8 April 2021 \\
\hline Last Revissions & 22 Mei 2021 \\
\hline Accepted & 23 Mei 2021 \\
\hline Copyedits Approved & 3 Juni 2021 \\
\hline
\end{tabular}

\begin{abstract}
Abstrack
Film as a cinematographic work is an object protected by copyright. Film and ICT are rapidly growing in Indonesia. Along with this, digital piracy occurs very often. This happens in an instant messaging application, Telegram. Public channel is an available feature on Telegram that is misused by its users to spread films illegally. This research was conducted to determine regulations about accessing cinematography on Telegram and Telegram Messenger Inc. liability concerns accessing cinematography by its users. The method is juridical normative by examining secondary data from primary, secondary, and tertiary legal materials obtained through literature study related to copyright and over-the-top services. The results show that accessing cinematography on Telegram violates economic rights according to Article 9 (1) b Copyright Law which is categorized as piracy in accordance with Article 113 (4) Copyright Law and Telegram Messenger Inc. as application organizer should be responsible secondarily for piracy in a civil lawsuit according to Article 99 Copyright Law and Article 38 ITE Law, administrative and criminal that occurs due to negligence in monitoring the activities of its users. Then, primary liability can be requested to application users who do not obey the terms of services of the telegram application which has an exoneration clause as a way to prevent copyright infringement in telegram application.
\end{abstract}

Keywords: Copyright; Film Piracy; Liability. 


\section{A. PENDAHULUAN}

Hak cipta merupakan salah satu rezim yang terdapat dalam hak kekayaan intelektual (HKI). HKI merupakan hak yang berasal dari kegiatan kreatif suatu kemampuan daya pikir manusia yang diekspresikan kepada khalayak umum dalam berbagai bentuknya yang memiliki manfaat serta berguna dalam menunjang kehidupan manusia, juga memiliki nilai ekonomi. ${ }^{1}$ Di Indonesia sendiri pengaturan terkait Hak atas Kekayaan Intelektual (HKI) terkhusus hak cipta bukanlah suatu hal yang baru. Hal tersebut dapat terlihat dari beberapa kali perubahan yang terjadi pada undang-undang hak cipta. Berdasarkan Pasal 1 angka 1 Undang-Undang Nomor 28 Tahun 2014 tentang Hak Cipta (UU HC) bahwa Hak cipta adalah hak eksklusif pencipta yang timbul secara otomatis berdasarkan prinsip deklaratif setelah suatu ciptaan diwujudkan dalam bentuk nyata tanpa mengurangi pembatasan sesuai dengan ketentuan peraturan perundang-undangan.

Dalam pemberian hak eksklusif kepada pencipta terdapat dua hak yang fundamental yaitu hak moral dan hak ekonomi. Hak moral merupakan hak yang melekat pada pencipta dan tidak dapat dialihkan sedangkan hak ekonomi merupakan hak pencipta untuk mendapatkan manfaat ekonomi atas ciptaannya. Hak moral ini membantu pencipta untuk melarang seseorang untuk mengubah atau mengurangi hasil dari ciptaannya tanpa seizin dari pencipta. $^{2}$ Perlindungan hak cipta terdiri dari bidang ilmu pengetahuan, seni, dan sastra, salah satu karya seni yang dilindungi oleh hak cipta yaitu film. Film adalah karya seni budaya yang merupakan pranata sosial dan media komunikasi massa yang dibuat berdasarkan kaidah sinematografi dengan atau tanpa suara dan dapat dipertunjukkan. Melihat dari penjelasan tersebut maka film sebagai karya sinematografi mendapatkan perlindungan hak cipta.

Secara umum karya sinematografi adalah segala hal mengenai sinema (perfilman) baik dari estetika, bentuk, fungsi, makna, produksi, proses, maupun penontonnya. Dunia sinematografi dalam hal ini menyangkut pemahaman estetik melalui paduan seni akting, fotografi, teknologi optik, komunikasi visual, industri perfilman, ide, cita-cita dan imajinasi yang sangat kompleks. Film sebagai karya sinematografi merupakan karya yang bercerita secara visual yang diwujudkan dalam bentuk film dan dalam proses pembuatan karya tersebut memperhatikan berbagai macam aspek teknis serta pemahaman estetik. Dalam hal ini, film memiliki beberapa jenis yaitu seperti film dokumenter, film iklan, film cerita, dan film kartun.

Film sebagai karya sinematografi dapat dibuat dalam bentuk pita seluloid, pita video, piringan video, cakram optik atau media lainnya yang dapat dipertunjukkan. Film sebagai

\footnotetext{
1 Darwance Darwance, Yokotani Yokotani, and Wenni Anggita, "Dasar-Dasar Pemikiran Perlindungan Hak Kekayaan Intelektual,” PROGRESIF: Jurnal Hukum 15, no. 2 (2020): 193-208, https://doi.org/10.33019/progresif.v15i2.1998.

${ }^{2}$ Henry Soelistyo, Hak Cipta Tanpa Hak Moral (Jakarta: PT Raja Grafindo Persada, 2011). hlm. 14.
} 
karya sinematografi dilindungi oleh hak cipta selama 50 (lima puluh) tahun sejak pertama kali dilakukan pengumuman. Perkembangan dunia perfilman di Indonesia pada saat ini dapat dikatakan berkembang sangat pesat. Hal ini dikarenakan banyak film hasil karya anak bangsa yang lolos ke dunia film internasional. Di tengah berkembangnya karya sinematografi, pada saat ini terjadi juga perkembangan yang pesat dalam bidang teknologi informasi dan komunikasi. Teknologi Informasi dan Komunikasi adalah payung besar terminologi yang mencakup seluruh peralatan teknis untuk memproses dan menyampaikan informasi. ${ }^{3}$ Perkembangan teknologi informasi dan komunikasi tentunya memberikan kemudahan untuk masyarakat dalam menjalankan aktivitasnya sehari-hari, salah satunya terdapat jaringan internet. Perkembangan teknologi informasi dan komunikasi yang pesat telah mempengaruhi dan mengubah berbagai pola kehidupan manusia, salah satunya dengan membentuk masyarakat informasi (information society) melalui internet. ${ }^{4}$ Tidak sekedar memenuhi kebutuhan primer, penggunaan internet dapat memenuhi kebutuhan hiburan masyarakat yaitu menonton film.

Saat ini, menonton film dapat dilakukan secara online melalui aplikasi yang menyediakan layanan streaming film secara legal yang dapat diakses menggunakan internet. Hal tersebut merupakan salah satu bentuk layanan over the top (OTT). Layanan OTT diimplementasikan dalam bentuk aplikasi dan layanan aplikasi, bentuk video dan audio streaming, messaging (kirim terima pesan instan), dan jejaring sosial, memanfaatkan koneksi internet dari penyedia (dalam hal ini operator/penyedia telekomunikasi) dan berbasis mobile. ${ }^{5}$ Dengan demikian, karya sinematografi dengan penggunaan internet merupakan kedua hal yang berhubungan dan tidak dapat dipisahkan. Penggunaan internet dapat mengakibatkan dampak negatif, salah satu dampaknya yaitu sering terjadi pelanggaran hak cipta berupa pembajakan karya secara digital. Kecanggihan yang disediakan oleh internet banyak disalahgunakan oleh para oknum untuk melakukan pembajakan karya terkhusus pembajakan film.

Pelanggaran hak cipta pada bidang karya sinematografi ini tentunya merugikan pihak-pihak yang bersangkutan baik secara moril dan materil. Terlebih pembajakan film tersebut sangat mempengaruhi penghasilan yang seharusnya didapatkan oleh pihak-pihak yang bersangkutan karena tidak mendapatkan royalti sesuai dengan jumlah yang seharusnya didapatkan. Oleh karena itu, pembajakan film tersebut sangat merugikan hak ekonomi bagi pencipta karya sinematografi. Terkait pembajakan film secara digital, hal tersebut terjadi pada suatu aplikasi pesan instan yaitu Telegram. Telegram merupakan wujud dari

\footnotetext{
${ }^{3}$ Rahartri, “'Whatsapp' Media Komunikasi Efektif Masa Kini (Studi Kasus Pada Layanan Jasa Informasi Ilmiah Di Kawasan Puspiptek)," Visi Pustaka 21, no. 2 (2019): 147-156.

${ }^{4}$ Muhammad. Amirulloh, Hukum Teknologi Informasi Dan Komunikasi (TIK) Sebagai Hukum Positif Di Indonesia Dalam Perkembangan Masyarakat Global (Bandung: Unpad Press, 2016). hlm. 1

5 Ahmad Budi Setiawan, "Pengembangan Kebijakan Terhadap Penyediaan Layanan Aplikasi Dan Konten Pada Ekosistem Digital Melalui Over The Top," Jurnal Penelitian Pos Dan Informatika 8, no. 2 (2018): 169-84, https://doi.org/10.17933/jppi.2018.080206.
} 
penyelenggaraan sistem elektronik sesuai dengan Undang-Undang Nomor 19 Tahun 2016 tentang Perubahan Atas Undang-Undang Nomor 11 Tahun 2008 tentang Informasi dan Transaksi Elektronik (UU ITE). Aplikasi telegram memiliki fitur yang menarik, salah satunya fitur global search yang bertujuan agar dapat mencari public channel. Public channel merupakan suatu kelompok chat dengan sistem subscribers yang dapat mengirimkan pesan secara massal.

Fitur-fitur yang tersedia tersebut disalahgunakan oleh para pengguna aplikasi telegram dengan cara membentuk public channel untuk penyebaran film secara ilegal. Public channel tersebut dibentuk oleh pengguna telegram dikarenakan keinginan menonton film dengan cara instan yang tidak memerlukan pengeluaran biaya yang besar. Selain itu, pada public channel pengguna dapat menonton bahkan mengunduh film yang tersedia secara gratis. Kecanggihan fitur yang disediakan, penggunaan internet yang mudah, dan tingginya biaya menonton film di bioskop merupakan faktor yang menyebabkan seseorang menonton atau mengunduh film secara ilegal. Terlebih masih rendahnya budaya masyarakat Indonesia dalam menghormati suatu karya yang dilindungi hak cipta merupakan salah satu faktor yang menyebabkan terjadinya pelanggaran hak cipta terkhusus pada pembajakan film.

Pada faktanya, public channel yang digunakan untuk penyebaran film secara ilegal sudah termasuk pelanggaran hak cipta di bidang sinematografi. Walaupun disediakan secara gratis namun tidak menutup fakta bahwa perbuatan pengguna aplikasi telegram yang menyebarkan film secara ilegal sudah termasuk ke dalam perbuatan pembajakan film. Sebagaimana tercantum pada Pasal 40 ayat (1) huruf m UU HC, sinematografi termasuk karya yang dilindungi oleh hak cipta sehingga seharusnya pengaksesan sinematografi dalam aplikasi telegram harus memiliki izin terlebih dahulu demi memenuhi hak eksklusif yang dimiliki pencipta. Lebih lanjut, pihak telegram seharusnya dapat mengkaji terhadap fitur global search yang tersedia karena pada dasarnya public channel yang menyebarkan film secara ilegal dilakukan oleh pengguna aplikasi telegram saja tanpa melibatkan pihak telegram sebagai pihak yang menyediakan fitur tersebut. Mengacu pada Pasal 15 ayat (2) UU ITE menyatakan Penyelenggara Sistem Elektronik bertanggung jawab terhadap Penyelenggaraan Sistem Elektroniknya. Oleh karena itu, pertanggungjawaban pihak telegram sebagai penyelenggara aplikasi merupakan suatu hal yang penting demi memberikan perlindungan terhadap karya sinematografi.

Berdasarkan uraian yang telah dipaparkan pada latar belakang, maka penulis merumuskan rumusan masalah sebagai berikut: Pertama, bagaimana pengaturan terhadap pengaksesan sinematografi pada aplikasi telegram berdasarkan UU HC dan UU ITE. Kedua, bagaimana pertanggungjawaban pihak Telegram Messenger Inc. terhadap pengaksesan sinematografi oleh penggunanya berdasarkan Undang-Undang Hak Cipta dan UndangUndang Informasi dan Transaksi Elektronik.

Perlindungan Hukum Sinematografi Terhadap Pengaksesan Tanpa Hak oleh Pengguna Aplikasi Telegram Berdasarkan Undang-Undang Hak Cipta dan Undang-Undang Informasi Dan Transaksi Elektronik Di Indonesia 


\section{B. METODE PENELITIAN}

Dalam penelitian ini, metode pendekatan yang digunakan adalah yuridis normatif yaitu untuk mengkaji asas-asas dan norma hukum yang terdapat dalam peraturan perundangundangan terkait yaitu Undang-Undang Nomor 28 Tahun 2014 tentang Hak Cipta dan Undang-Undang Nomor 11 Tahun 2008 Jo. Undang-Undang Nomor 19 Tahun 2016 tentang Informasi dan Transaksi Elektronik. Spesifikasi penelitian dilakukan secara deskriptif analisis, yaitu penelitian dengan menggambarkan permasalahan yang didasarkan pada data yang kemudian dianalisis lebih lanjut untuk diambil sebuah kesimpulan. Teknik pengumpulan data dilakukan secara studi kepustakaan yaitu mengumpulkan materi dengan cara membaca peraturan perundang-undangan, buku-buku, dan sumber kepustakaan lainnya yang berhubungan dengan objek penelitian. Untuk metode analisis data yang digunakan adalah yuridis normatif bersifat kualitatif yaitu data yang diperoleh disusun secara sistematis untuk mendapatkan kesimpulan yang mengandung kebenaran obyektif.

\section{HASIL DAN PEMBAHASAN}

\section{Pengaturan Terhadap Pengaksesan Sinematografi pada Aplikasi Telegram Berdasarkan Undang-Undang Hak Cipta dan Undang-Undang Informasi dan Transaksi Elektronik}

Film sebagai karya sinematografi merupakan salah satu objek yang dilindungi oleh hak cipta. Hak Cipta tidak melindungi ide semata, tetapi pengungkapan dari ide tersebut dalam bentuk yang nyata. ${ }^{6}$ Perlindungan hak cipta diberikan kepada karya yang memiliki ciri khas atas dasar kemampuannya yang kemudian diberikan suatu hak eksklusif kepada pencipta atau pemegang hak cipta. Hak eksklusif yang dimiliki pencipta atau pemegang hak cipta diwujudkan dalam bentuk hak moral dan hak ekonomi. Hak moral merupakan hak yang melekat secara abadi pada diri pencipta walaupun hak cipta tersebut dialihkan, sedangkan hak ekonomi merupakan hak eksklusif pencipta atau pemegang hak cipta untuk mendapatkan manfaat ekonomi atas Ciptaan. Hak ekonomi tersebut berupa keuntungan sejumlah uang yang diperoleh karena penggunaan sendiri kekayaan intelektual atau karena penggunaan pihak lain berdasarkan lisensi. ${ }^{7}$

Hak eksklusif yang diberikan kepada pencipta merupakan suatu bentuk penghargaan atas usaha si pencipta dalam menghasilkan suatu karya. Hal tersebut merupakan salah satu bentuk penerapan reward theory dari Robert M. Sherwood dalam memberikan perlindungan terhadap hak kekayaan intelektual. Berdasarkan Pasal 59 ayat (1) UU HC, film sebagai karya sinematografi diberikan perlindungan hak cipta selama 50 (lima puluh) tahun setelah dilakukan pengumuman. Dengan demikian, jika tidak mengalihkan hak ekonomi yang dimiliki maka selama 50 (lima puluh) tahun tersebut

\footnotetext{
${ }^{6}$ Muhammad. Amirulloh and Helitha Novianti Muchtar, Buku Ajar Hukum Kekayaan Intelektual (Bandung: Unpad Press, 2016). hlm. 55.

${ }^{7}$ Gatot Supramono, Hak Cipta Dan Aspek-Aspek Hukumnya (Jakarta: Rineka Cipta, 2010). hlm 45.
} 
pencipta atau pemegang hak cipta karya sinematografi tetap memiliki hak ekonomi dari film yang diciptakannya. Pada zaman sekarang, film sebagai karya sinematografi tidak hanya dapat dinikmati di bioskop saja. Seiring dengan berkembangnya teknologi, terdapat banyak aplikasi yang memberikan layanan untuk streaming film secara online. Namun, perkembangan tersebut juga memunculkan dampak negatif yaitu seperti pembajakan film di dunia siber. Saat ini sangat marak terjadi pengaksesan film secara ilegal pada aplikasi telegram yang merupakan aplikasi pesan instan yang diakses melalui internet yang tersedia dalam bentuk aplikasi dan website.

Pada aplikasi telegram, film yang tersedia sengaja disebarkan oleh pengguna aplikasi dengan cara membentuk public channel. Public channel merupakan fitur yang tersedia pada aplikasi telegram yang digunakan untuk melakukan pengiriman pesan secara massal kepada subscribers yang bergabung pada channel tersebut. Seluruh pengguna aplikasi telegram memiliki fitur untuk mendirikan public channel. Pencarian public channel dapat ditemukan dengan menggunakan fitur global search dengan cara memasukkan username public channel. Saat ini penggunaan public channel banyak disalahgunakan oleh pengguna aplikasi telegram dengan dijadikan tempat untuk menyebarkan film secara ilegal yang dapat diakses oleh seluruh pengguna aplikasi telegram dengan gratis. Film yang tersedia pada public channel dapat dengan mudah diakses oleh para pengguna aplikasi telegram baik untuk ditonton secara langsung atau diunduh terlebih dahulu. Pengaksesan yang sangat mudah ini menyebabkan penyebaran film pada aplikasi telegram terus meningkat.

Berdasarkan laman Telegram FAQ menyatakan bahwa ketika pengguna aplikasi telegram mengunggah dokumen pada public channel bukan merupakan bagian dari inti penyelenggaraan aplikasi telegram. Dengan demikian, penyebaran film pada public channel tersebut sudah bukan merupakan pengelolaan yang dilakukan oleh pihak Telegram Messenger Inc. melainkan pengelolaan utama yang dilakukan oleh pengguna sebagai pendiri public channel tersebut. Selain itu, pihak Telegram Messenger Inc. memberikan layanan agar pencipta atau pemegang hak cipta yang haknya dilanggar dapat melaporkan kepada pihak Telegram Messenger Inc. agar konten tersebut segera di-take down pada aplikasi telegram.

Pengaksesan film pada public channel aplikasi telegram merupakan bentuk pelanggaran hak cipta terhadap karya sinematografi dikarenakan tidak memiliki izin dari pencipta atau pemegang hak cipta. Pelanggaran hak cipta yaitu penggunaan karya cipta yang melanggar hak eksklusif pemegang hak cipta, seperti hak untuk memproduksi, mendistribusikan, menampilkan atau memamerkan karya berhak cipta, atau membuat 
karya turunan, tanpa izin dari pemegang hak cipta, yang biasanya penerbit atau usaha lain yang mewakili atau ditugaskan oleh pencipta karya tersebut. ${ }^{8}$

Berdasarkan UU HC, penyebaran suatu film harus didasari izin dari pencipta atau pemegang hak cipta untuk memenuhi hak eksklusif yang dimilikinya. Pemberian izin dari pencipta atau pemegang hak cipta kepada orang lain itulah yang disebut lisensi. ${ }^{9}$ Dengan demikian, karya sinematografi sebagai objek hak cipta baru dapat digunakan oleh pihak lain setelah mendapatkan izin dari pencipta atau pemegang hak cipta. Namun, penyebaran film yang dilakukan oleh pengguna aplikasi telegram pada public channel tersebut tidak didasari izin pencipta atau pemegang hak cipta dari film yang disebarkan.

Penyebaran film secara ilegal pada aplikasi telegram ini disebarkan oleh pengguna aplikasi sebagai pendiri public channel yang mana perbuatan tersebut mendapatkan keuntungan ekonomi berupa penambahan subscribers public channel dan tawaran paid promote dari online shop. Hal ini dikarenakan banyaknya subscribers public channel yang meningkatkan engagement public channel tersebut sehingga membuat para pemilik online shop tertarik untuk memasang iklan dengan cara paid promote. Paid promote merupakan jasa dalam mempromosikan barang atau jasa di media sosial, dengan menggunakan jasa tersebut dapat membantu online shop mempromosikan produk atau jasa yang mereka jual. ${ }^{10}$ Penyebaran film yang terjadi pada aplikasi telegram telah melanggar hak ekonomi pencipta atau pemegang hak cipta yang diatur pada Pasal 9 ayat (1) huruf b UU HC yang menyatakan Pencipta atau Pemegang Hak Cipta sebagaimana dimaksud dalam Pasal 8 memiliki hak ekonomi untuk melakukan: penggandaan Ciptaan dalam segala bentuknya. Hal tersebut dikarenakan mengacu pada Pasal 9 ayat (2) UU HC menyatakan bahwa Setiap Orang yang melaksanakan hak ekonomi sebagaimana dimaksud pada ayat (1) wajib mendapatkan izin Pencipta atau Pemegang Hak Cipta. Pada dasarnya, hak cipta bertujuan melindungi hak pembuat dalam mendistribusikan, menjual, atau membuat turunan dari karya tersebut. ${ }^{11}$ Dengan demikian, dalam kasus ini pihak pendiri public channel di aplikasi telegram telah melakukan penggandaan ciptaan yaitu film sebagai objek hak cipta yang disebarkan tanpa izin.

Pasal 1 angka 12 UU HC menyatakan bahwa penggandaan adalah proses, perbuatan, atau cara menggandakan satu salinan Ciptaan dan/atau fonogram atau lebih dengan cara dan dalam bentuk apapun, secara permanen atau sementara. Film-film yang tersedia pada public channel dapat ditonton langsung dan diunduh oleh pengguna aplikasi

\footnotetext{
${ }^{8}$ Henry Soelistyo, Plagiarisme: Pelanggaran Hak Cipta Dan Etika (Yogyakarta: Kanisius, 2016). hlm. 15.

${ }^{9}$ Soelistyo. hlm. 47.

${ }^{10}$ Nanda Putri Arifah and Carolina Novi Mustikarini, "Paid Promote Sebagai Media Promosi Produk Delicy Dalam Meningkatkan Konsumen Potensial,” Jurnal Manajemen Dan Start-Up Bisnis 1, no. 3 (2016): 307-313.

${ }^{11}$ Arya Utama, Titin Titawati, and Aline Febriyani Loilewen, "Perlindungan Hukum Terhadap Hak Cipta Lagu Dan Musik Menurut Undang-Undang Nomor 28 Tahun 2004,” Ganec Swara 13, no. 1 (2019): 78-83, https://doi.org/10.35327/gara.v13i1.65.
} 
telegram secara gratis. Proses pengunduhan film tersebut termasuk proses penggandaan karena telah menambahkan jumlah film tersebut dari satu file yang ada di situs internet menjadi dua termasuk dengan hasil pengunduhan. ${ }^{12}$ Maka dari itu, penyebaran film pada aplikasi telegram dapat dikategorikan sebagai bentuk pelanggaran hak ekonomi dalam penggandaan ciptaan dalam segala bentuknya yang dilakukan dalam bentuk pembajakan pada layanan OTT. Karena ketika terjadinya suatu pembajakan oleh oknum yang tidak bertanggung jawab, royalty atau keuntungan yang menjadi hak dari si pencipta tidak didapatkan oleh si pencipta. ${ }^{13}$

Perbuatan pendiri public channel yang sengaja menyebarkan film sehingga mendapatkan keuntungan ekonomi dikategorikan sebagai bentuk pembajakan sesuai dengan definisi pembajakan yang diatur dalam UU HC. Perbuatan pembajakan sendiri diatur pada Pasal 113 ayat (4) UU HC yang menyatakan Setiap Orang yang memenuhi unsur sebagaimana dimaksud pada ayat (3) yang dilakukan dalam bentuk pembajakan, dipidana dengan pidana penjara paling lama 10 (sepuluh) tahun dan/atau pidana denda paling banyak Rp. 4.000.000.000,00 (empat miliar rupiah). Lebih lanjut, film yang disebarkan pada aplikasi telegram merupakan sebuah dokumen elektronik. Mengacu pada UU ITE, perbuatan menyebarkan dokumen elektronik yang dilindungi hak cipta termasuk ke perbuatan yang dilarang yang diatur pada Pasal 32 ayat (1) dan (2) UU ITE dikarenakan penyebaran film pada public channel tersebut merupakan suatu proses menambah film dalam bentuk dokumen elektronik melalui proses transmisi dan memindahkan dokumen elektronik tersebut ke sistem elektronik orang lain yang tidak berhak. Dengan demikian, perbuatan menyebarkan film pada aplikasi telegram dapat dijatuhi sanksi pidana yang diatur pada Pasal 48 ayat (1) dan (2) UU ITE. Selain itu, pengguna aplikasi telegram dengan sengaja mengakses public channel untuk memperoleh film yang tersedia pada aplikasi telegram terkategori sebagai perbuatan yang dilarang pada Pasal 30 ayat (2) UU ITE karena perbuatan tersebut terkategori sebagai pelanggaran hak cipta. Maka dari itu perbuatan tersebut dapat juga dijatuhi sanksi pidana yang diatur pada Pasal 46 ayat (2) UU ITE yaitu Setiap Orang yang memenuhi unsur sebagaimana dimaksud dalam Pasal 30 ayat (2) dipidana dengan pidana penjara paling lama 7 (tujuh) tahun dan/atau denda paling banyak Rp. 700.000.000,00 (tujuh ratus juta rupiah).

Dengan demikian, peraturan perundang-undangan di Indonesia sebenarnya telah memberikan perlindungan hukum secara preventif dan represif terkait pengaksesan sinematografi pada layanan OTT yaitu aplikasi telegram. Perlindungan hukum preventif

\footnotetext{
12 Ayup Suran Ningsih and Balqis Hediyati Maharani, "Penegakan Hukum Hak Cipta Terhadap Pembajakan Film Secara Daring," Jurnal Meta Yuridis 2, no. 1 (2019): 13-32, https://doi.org/10.26877/m-y.v2i1.3440.

${ }^{13}$ Oksidelfa Yanto, "Konsep Perlindungan Hak Cipta Dalam Ranah Hukum Hak Kekayaan Intelektual (Studi Kritis Pembajakan Karya Cipta Musik Dalam Bentuk VCD Dan DVD),” Yustisia Jurnal Hukum 93, no. 3 (2015): 74660, https://doi.org/10.20961/yustisia.v93i0.3702.
}

Perlindungan Hukum Sinematografi Terhadap Pengaksesan Tanpa Hak oleh Pengguna Aplikasi Telegram Berdasarkan Undang-Undang Hak Cipta dan Undang-Undang Informasi Dan Transaksi Elektronik Di Indonesia 
merupakan sebuah bentuk perlindungan yang mengarah pada tindakan yang bersifat pencegahan. ${ }^{14}$ Dalam hal ini, berdasarkan UU HC dan UU ITE pengaksesan film pada aplikasi telegram terkategori sebagai pembajakan dikarenakan penyebaran serta pengaksesan film yang terjadi pada aplikasi telegram tidak didasari izin pencipta atau pemegang hak cipta. Selain itu, pihak Telegram Messenger Inc. sebenarnya sudah menyatakan bahwa dokumen yang diunggah pada public channel tersebut merupakan pengelolaan utama dari pengguna aplikasi yang mendirikan public channel dan pengguna aplikasi harus mematuhi terms of services yang berlaku sebagai upaya preventif yang diberikan pihak Telegram Messenger Inc. agar meminimalisir terjadinya pelanggaran hak cipta pada aplikasi telegram. Lalu untuk perlindungan hukum represif merupakan perlindungan akhir berupa sanksi seperti denda, penjara, dan hukuman tambahan yang diberikan apabila sudah terjadi sengketa atau telah dilakukan suatu pelanggaran. ${ }^{15}$ Pengaksesan film yang terjadi pada aplikasi telegram ini merugikan pihak pencipta atau pemegang hak cipta yang filmnya tersebar sehingga pengaksesan film yang dilakukan oleh pengguna aplikasi telegram dapat dijatuhi sanksi sebagaimana telah diatur pada UU HC dan UU ITE. Perlindungan hukum represif ini merupakan bentuk perlindungan terakhir yang diberikan yang bersifat tegas untuk mengatasi pelanggaran hak cipta yang terjadi pada aplikasi telegram.

\section{Pertanggungjawaban Pihak Telegram Messenger Inc. Terhadap Pengaksesan Sinematografi oleh Penggunanya Berdasarkan Undang-Undang Hak Cipta dan Undang-Undang Informasi dan Transaksi Elektronik}

Pengaksesan film pada aplikasi telegram terkategori sebagai pembajakan film secara digital. Berdasarkan peraturan perundang-undangan di Indonesia terdapat perlindungan hukum baik secara preventif yaitu berupa pencegahan dan represif yaitu berupa sanksi secara perdata, pidana, dan administratif terkait pelanggaran hak cipta yang terjadi khususnya pembajakan film pada layanan OTT. Pembajakan film yang dilakukan oleh pengguna aplikasi telegram ini tentunya melanggar hak eksklusif yang dimiliki oleh pencipta atau pemegang hak cipta. Berdasarkan UU HC, pencipta atau pemegang hak cipta memiliki hak untuk menyelesaikan permasalahan tersebut melalui alternatif penyelesaian sengketa, arbitrase, atau pengadilan. Pencipta atau pemegang hak cipta lebih diutamakan menyelesaikan permasalahan melalui alternatif penyelesaian sengketa yaitu mediasi, hal ini dikarenakan keputusan yang diambil merupakan kesepakatan para pihak yang bersifat win-win solution. Namun mengacu pada Pasal 95 ayat (4) UU HC

\footnotetext{
${ }^{14}$ Ronna Novy Yosia Taliwongso, "Perlindungan Hukum Atas Hak Kekayaan Intelektual Khususnya Merek Di Indonesia," Lex et Societatis II, no. 7 (2014): 147-158.

${ }^{15}$ Tommy Marbun, T Devi, and Windha Windha, "Perlindungan Hukum Hak Cipta Terhadap Karya Cipta Lagu Dan Musik Dalam Bentuk Ringtone Pada Telepon Seluler," Transparency 1, no. 1 (2013).
} 
penyelesaian yang mengharuskan melalui proses mediasi hanya dapat dilakukan terhadap pelanggaran hak cipta selain pembajakan.

Dikarenakan permasalahan yang terjadi pada aplikasi telegram ini dapat dikategorikan sebagai bentuk pembajakan, maka pihak pencipta atau pemegang hak cipta dapat mengajukan gugatan perdata yang diajukan ke pengadilan niaga. Berdasarkan Pasal 99 UU HC, gugatan yang diajukan oleh pencipta atau pemegang hak cipta dapat dimintakan ganti rugi serta penghentian kegiatan pembajakan tersebut. Selain itu dikarenakan pembajakan film terjadi secara digital maka mengacu pada Pasal 38 ayat (1) UU ITE menyatakan pencipta atau pemegang hak cipta dapat mengajukan gugatan perdata tersebut kepada pihak penyelenggara sistem elektronik maupun pengguna yang melakukan penyebaran film. Selanjutnya, pencipta atau pemegang hak cipta juga dapat melaporkan pembajakan yang terjadi terhadap kepolisian Indonesia untuk dilakukan penuntutan secara pidana. Dalam hal ini, mengacu pada Pasal 113 ayat (4) UU HC pembajakan tersebut diancam pidana penjara paling lama 10 tahun dan denda paling banyak Rp. 4.000.000.000,00. Lalu penuntutan pidana juga dapat didasarkan pada ketentuan UU ITE terkait perbuatan yang dilarang dalam melakukan kegiatan di dunia internet.

Langkah-langkah tersebut dapat dilakukan oleh pihak pencipta atau pemegang hak cipta yang hak eksklusifnya terlanggar dengan mengacu ketentuan UU HC dan UU ITE. Terkait pembajakan pada public channel aplikasi telegram, pencipta atau pemegang hak cipta juga sebenarnya sudah diberikan upaya serta kepastian oleh pihak Telegram Messenger Inc. Hal tersebut dapat terlihat dari laman Telegram FAQ yang menyatakan pencipta atau pemegang hak cipta dapat melaporkan pembajakan yang terjadi dengan cara mengirimkan email ke pihak Telegram Messenger Inc. Pelaporan tersebut akan ditindaklanjuti oleh pihak Telegram Messenger Inc. dengan cara men-take down public channel yang menyebarkan film. Dengan demikian, baik dalam peraturan perundangundangan maupun kebijakan pihak Telegram Messenger Inc. sudah memberikan perlindungan hukum terhadap film sebagai objek hak cipta dalam layanan OTT.

Dalam permasalahan yang terjadi, pihak Telegram Messenger Inc. telah lalai memantau aktivitas penggunanya karena sampai saat ini sudah banyak public channel yang sengaja dibentuk untuk menyebarkan film secara ilegal yang merugikan pihak pencipta dan pemegang hak cipta. Mengacu pada Pasal 99 ayat (1) UU HC, pencipta atau pemegang hak cipta yang merasa dirugikan dapat mengajukan gugatan ganti rugi kepada pihak Telegram Messenger Inc. Selain itu, mengacu pada Pasal 38 ayat (1) UU ITE, pihak penyelenggara aplikasi dapat dimintai pertanggungjawaban secara perdata. Dengan demikian, pihak pencipta atau pemegang hak cipta dapat mengajukan gugatan perdata terhadap penyelenggara sistem elektronik atau pengguna sistem elektronik yang 
perbuatannya menyebabkan terlanggarnya hak eksklusif yang dimiliki pencipta atau pemegang hak cipta. Lebih lanjut, pihak Telegram Messenger Inc. dapat dikategorikan telah melakukan perbuatan melawan hukum sebagaimana diatur pada Pasal 1365 KUHPerdata yang memiliki unsur-unsur yaitu adanya perbuatan melawan hukum, adanya kesalahan, adanya kausalitas antara kerugian dan perbuatan, dan adanya kerugian. Keempat unsur tersebut telah terpenuhi dikarenakan kelalaian yang dilakukan pihak Telegram Messenger Inc. merugikan pihak pencipta atau pemegang hak cipta yang filmnya tersebar dan dapat diakses pada public channel aplikasi telegram. Terlebih berdasarkan Pasal 1366 KUHPerdata, setiap orang bertanggung jawab bukan hanya kerugian yang disebabkan perbuatannya melainkan juga atas kerugian yang disebabkan kelalaian.

Berdasarkan Pasal 113 ayat (4) UU HC pihak Telegram Messenger Inc. dapat dimintakan pertanggungjawaban secara pidana terhadap pembajakan yang terjadi. Hal ini dikarenakan penyelenggara aplikasi telegram sebenarnya sudah mengetahui adanya pembajakan film yang terjadi pada aplikasinya berdasarkan laporan dari pihak pencipta atau pemegang hak cipta namun tidak bertindak tegas untuk men-take down film tersebut. Secara tidak langsung, pihak Telegram Messenger Inc. telah lalai dalam menjalankan kewajibannya sebagai pihak penyelenggara sistem elektronik. Pihak Telegram Messenger Inc. juga dapat dikenakan sanksi pidana sesuai Pasal 50 UU ITE, hal ini dikarenakan pihak Telegram Messenger Inc. secara tidak langsung memenuhi unsur Pasal 34 ayat (1) huruf $\mathrm{b}$ UU ITE karena telah memfasilitasi penggunanya melakukan perbuatan yang dilarang yang diatur pada Pasal 30 ayat (2), Pasal 32 ayat (1) dan (2) UU ITE. Selain itu, dikarenakan pengaksesan film pada aplikasi telegram telah merugikan orang lain khususnya pihak pencipta atau pemegang hak cipta maka sesuai dengan Pasal 36 UU ITE hal tersebut dapat dijatuhi sanksi pidana yang diatur pada Pasal 51 ayat (2) UU ITE. Penjatuhan tersebut dapat dikenakan kepada pihak Telegram Messenger Inc. yang merupakan badan hukum asing karena ketentuan pada UU ITE bersifat lintas teritorial.

Terkait pertanggungjawaban pidana dapat dikenakan terhadap pihak Telegram Messenger Inc. karena fitur pembentukan public channel dan global search yang tersedia pada aplikasi telegram merupakan suatu sarana yang disalahgunakan oleh penggunanya untuk melakukan pembajakan film. Dengan demikian sesuai dengan Pasal 56 KUHP, pihak Telegram Messenger Inc. dapat dimintai pertanggungjawaban pidana karena terkategori pembantuan melakukan kejahatan. Namun untuk penjatuhan sanksi pidana tersebut harus dapat membuktikan unsur kesengajaan yang dilakukan pihak Telegram Messenger Inc. dalam terjadinya pembajakan film pada aplikasinya. Selanjutnya, berdasarkan Pasal 100 ayat (1) PP PSTE kelalaian penyelenggara aplikasi telegram dapat dikenakan sanksi administratif karena telah melanggar ketentuan Pasal 5 ayat (1) dan (2) PP PSTE yang mewajibkan penyelenggara memastikan sistem elektroniknya tidak 
memuat dan memfasilitasi penyebarluasan dokumen elektronik yang dilarang oleh ketentuan peraturan perundang-undangan. Sanksi administratif yang dijatuhkan dapat berupa teguran tertulis, denda administratif, penghentian sementara, pemutusan akses, serta dikeluarkan dari daftar. Penjatuhan sanksi administratif ini diberikan sesuai dengan pelanggaran yang telah dilakukan oleh pihak penyelenggara sistem elektronik dan berlaku kumulatif. Penjatuhan sanksi administratif dilakukan oleh Menteri Komunikasi dan Informatika dan penjatuhan sanksi tersebut tidak menghapuskan tanggung jawab secara pidana dan perdata.

Dibalik perlindungan hukum yang diatur oleh peraturan perundang-undangan Indonesia, pihak Telegram Messenger Inc. juga menyediakan layanan agar pencipta atau pemegang hak cipta dapat melaporkan kepada telegram terkait konten yang melanggar hak ciptanya dan pihak telegram memberikan aksi nyata terhadap laporan yang didapatkan yaitu dengan men-take down konten yang dikategorikan pelanggaran hak cipta. Lebih lanjut, melihat laman Telegram FAQ terdapat pernyataan bahwa pihak penyelenggara aplikasi telegram tidak menghendaki serta mendukung adanya pelanggaran hak cipta yang terjadi pada aplikasinya dan menyatakan bahwa pengunggahan dokumen pada public channel bukan merupakan bagian dari inti penyelenggaraan aplikasi telegram. Pernyataan pada laman Telegram FAQ tersebut secara tidak langsung menunjukkan bahwa pihak Telegram Messenger Inc. bukanlah pihak yang harus bertanggung jawab mutlak ketika pencipta atau pemegang hak cipta menuntut ganti rugi karena pelanggaran hak cipta yang terjadi. Hal tersebut merupakan salah satu tindakan penyedia jasa untuk mencegah terjadinya pelanggaran hak cipta melalui fasilitas yang mereka sediakan adalah dengan memasukan perjanjian berupa terms of services yang memberi batasan kepada pengguna dalam menggunakan jasa. ${ }^{16}$ Selain itu, pernyataan tersebut merupakan perwujudan dari klausula eksonerasi yang diatur pada Pasal 1493 KUHPerdata. Klausula eksonerasi tidak hanya menekankan pada prosedur pembuatan atau pencantumannya dalam kontrak, tetapi juga isinya yang bertujuan pengalihan kewajiban atau tanggung jawab pelaku usaha. ${ }^{17}$

Dengan demikian, pernyataan yang terdapat pada laman Telegram FAQ merupakan suatu bentuk tanggung jawab yang dapat dijatuhkan kepada pengguna aplikasi ketika melanggar ketentuan terms of services dari suatu aplikasi. Hal ini dikarenakan terms of services tersebut merupakan bentuk dari perjanjian antara penyedia jasa dengan pengguna, ada juga beberapa kebijakan (policy) yang diterbitkan oleh penyedia jasa sebagai peraturan dalam menggunakan jasanya. Terlebih, jika penyedia

${ }^{16}$ Jonathan A Friedman and Francis M Buono, "Limiting Tort Liability for Online Third-Party Content under Section 230 of the Communications Act," Federal Communications Law Journal 52, no. 3 (2000): 647-665.

${ }^{17}$ Az Nasution, Hukum Perlindungan Konsumen (Suatu Pengantar) (Jakarta: Diadit Media, 2002). hlm. 236-237. 
jasa bertanggung jawab atas semua konten bermasalah yang dipasang setiap orang dan menyelesaikannya satu persatu akan melemahkan internet. ${ }^{18}$

Dengan terjadinya pembajakan film pada aplikasi telegram menunjukkan bahwasannya pengguna aplikasi telegram telah melanggar ketentuan yang diatur pada terms of services aplikasi telegram. Dikarenakan terjadinya pelanggaran tersebut, pengguna aplikasi telegram yang melakukan penyebaran film secara ilegal dapat dimintai pertanggungjawaban secara primair oleh pihak pencipta atau pemegang hak cipta yang hak eksklusifnya terlanggar. Namun, mengacu pada Pasal 5 ayat (1) PP PSTE Penyelenggara Sistem Elektronik wajib memastikan Sistem Elektroniknya tidak memuat Informasi Elektronik dan/atau Dokumen Elektronik yang dilarang sesuai dengan ketentuan perundang-undangan. Maka dari itu, pihak Telegram Messenger Inc. seharusnya tetap dapat dimintai pertanggungjawaban terhadap kelalaiannya dalam memantau aktivitas pengguna yang melakukan pembajakan hak cipta.

Berdasarkan Pasal 1 angka 6a UU ITE pihak Telegram Messenger Inc. merupakan pihak penyelenggara sistem elektronik sehingga terkait penyelenggaraan sistem elektronik yang dijalankan di Indonesia harus mematuhi setiap peraturan perundang-undangan yang berlaku. Lalu merujuk pada Pasal 1 angka 5 UU ITE Sistem Elektronik adalah serangkaian perangkat dan prosedur elektronik yang berfungsi mempersiapkan, mengumpulkan, mengolah, menganalisis, menyimpan, menampilkan, mengumumkan, mengirimkan, dan/atau menyebarkan Informasi Elektronik. Penggunaan sistem elektronik ini dimanfaatkan oleh penyelenggara baik untuk keperluan sendiri maupun pihak lain. Dalam hal penyelenggaraan sistem elektronik tersebut harus memenuhi peraturan perundang-undangan di Indonesia dan jika terjadi pelanggaran maka sesuai dengan Pasal 15 ayat (2) UU ITE, Penyelenggara Sistem Elektronik bertanggung jawab terhadap Penyelenggaraan Sistem Elektroniknya. Lebih lanjut, berdasarkan Poin Nomor 5.4 Surat Edaran Menteri Komunikasi dan Informatika Nomor 3 Tahun 2016 tentang Penyediaan Layanan Aplikasi dan/atau Konten Melalui Internet (Over The Top) ("SE OTT") penyelenggara aplikasi bertanggung jawab secara penuh dalam menyediakan layanan OTT. Pada permasalahan pembajakan film pada aplikasi telegram, pihak Telegram Messenger Inc. sebagai penyelenggara sistem elektronik dapat dimintai pertanggungjawaban secara sekunder. Pertanggungjawaban merupakan perbuatan yang dilakukan oleh seseorang untuk memberikan pemulihan atas kerugian yang ditimbulkan. Dalam hal ini pertanggungjawaban merupakan kewajiban untuk melakukan suatu hal atau berperilaku berdasarkan aturan yang ada.

Pertanggungjawaban secara perdata, administratif, dan pidana yang diatur pada UU HC, UU ITE, dan PP PSTE tetap dapat dikenakan terhadap pihak Telegram

\footnotetext{
${ }^{18}$ Mark A. Lemley, "Rationalizing Internet Safe Harbors," J. on Telecomm. \& High Tech. L. 681 (2018): 291-309,
} https://doi.org/10.4324/9781315095400-9. 
Messenger Inc. sebagai penyelenggara aplikasi. Lebih lanjut, perlu dilihat juga sikap dan tanggapan pihak Telegram Messenger Inc. dalam memberantas pembajakan film yang terjadi pada public channel aplikasi telegram. Dengan demikian, pertanggungjawaban secara sekunder dapat dikenakan terhadap pihak Telegram Messenger Inc. karena telah lalai memantau aktivitas penggunanya sehingga menyebabkan pembajakan film terjadi pada aplikasinya.

\section{KESIMPULAN}

Pengaksesan karya sinematografi pada aplikasi telegram tidak didasari izin dari pihak pencipta atau pemegang hak cipta sehingga melanggar Pasal 9 ayat (1) huruf b Undang-Undang Hak Cipta dikarenakan penyebaran karya sinematografi yang dilakukan oleh pendiri public channel pada aplikasi telegram merupakan suatu bentuk penggandaan ciptaan dalam segala bentuknya. Penyebaran karya sinematografi tersebut memberikan keuntungan ekonomi bagi pendiri public channel sehingga perbuatannya terkategori sebagai pembajakan sebagaimana diatur pada Pasal 113 ayat (4) Undang-Undang Hak Cipta. Lebih lanjut, penyebaran karya sinematografi dalam bentuk dokumen elektronik merupakan perbuatan yang dilarang Pasal 30 ayat (2), Pasal 32 ayat (1) dan (2) Undang-Undang Informasi dan Transaksi Elektronik sehingga perbuatan tersebut dapat dijatuhi sanksi pidana sesuai Pasal 46 ayat (2), Pasal 48 ayat (1) dan (2) UU ITE. Selain itu, pengunggahan dokumen pada public channel merupakan pengelolaan utama dari pengguna aplikasi yang mendirikan public channel tersebut terlebih pengaksesan tersebut juga melanggar terms of services aplikasi telegram.

Pengaksesan karya sinematografi pada aplikasi telegram merupakan suatu bentuk pembajakan digital. Berdasarkan UU HC, UU ITE, dan PP PSTE, pihak Telegram Messenger Inc. dapat dimintai pertanggungjawaban baik secara perdata, pidana, maupun administratif. Pihak Telegram Messenger Inc. dapat dimintai pertanggungjawaban secara sekunder dikarenakan lalai dan tidak cepat tanggap dalam mengatasi pelanggaran hak cipta yang terjadi pada sistem elektroniknya. Lalu untuk pertanggungjawaban secara primair atau yang utama yaitu dimintakan kepada pihak pendiri public channel yaitu pengguna aplikasi yang secara langsung melakukan penyebaran karya sinematografi tanpa izin. Hal ini dikarenakan terdapat klausula eksonerasi pada terms of services aplikasi telegram sebagai upaya pencegahan terjadinya pelanggaran hak cipta melalui fasilitas yang disediakan oleh Telegram Messenger Inc. yang telah dilanggar oleh para pengguna tersebut. 


\section{DAFTAR PUSTAKA}

\section{Buku}

Amirulloh, Muhammad. Hukum Teknologi Informasi Dan Komunikasi (TIK) Sebagai Hukum Positif Di Indonesia Dalam Perkembangan Masyarakat Global. Bandung: Unpad Press, 2016.

Amirulloh, Muhammad., and Helitha Novianti Muchtar. Buku Ajar Hukum Kekayaan Intelektual. Bandung: Unpad Press, 2016.

Nasution, Az. Hukum Perlindungan Konsumen (Suatu Pengantar). Jakarta: Diadit Media, 2002. Soelistyo, Henry. Hak Cipta Tanpa Hak Moral. Jakarta: PT Raja Grafindo Persada, 2011.

—. Plagiarisme: Pelanggaran Hak Cipta Dan Etika. Yogyakarta: Kanisius, 2016.

Supramono, Gatot. Hak Cipta Dan Aspek-Aspek Hukumnya. Jakarta: Rineka Cipta, 2010.

\section{Jurnal}

Arifah, Nanda Putri, and Carolina Novi Mustikarini. "Paid Promote Sebagai Media Promosi Produk Delicy Dalam Meningkatkan Konsumen Potensial." Jurnal Manajemen Dan StartUp Bisnis 1, no. 3 (2016): 307-13.

Darwance, Darwance, Yokotani Yokotani, and Wenni Anggita. "Dasar-Dasar Pemikiran Perlindungan Hak Kekayaan Intelektual." PROGRESIF: Jurnal Hukum 15, no. 2 (2020): 193-208. https://doi.org/10.33019/progresif.v15i2.1998.

Friedman, Jonathan A, and Francis M Buono. "Limiting Tort Liability for Online Third-Party Content under Section 230 of the Communications Act." Federal Communications Law Journal 52, no. 3 (2000): 647-65.

Lemley, Mark A. "Rationalizing Internet Safe Harbors." J. on Telecomm. \& High Tech. L. 681 (2018): 291-309. https://doi.org/10.4324/9781315095400-9.

Marbun, Tommy, T Devi, and Windha Windha. "Perlindungan Hukum Hak Cipta Terhadap Karya Cipta Lagu Dan Musik Dalam Bentuk Ringtone Pada Telepon Seluler." Transparency 1, no. 1 (2013).

Rahartri. “Whatsapp' Media Komunikasi Efektif Masa Kini (Studi Kasus Pada Layanan Jasa Informasi Ilmiah Di Kawasan Puspiptek).”Visi Pustaka 21, no. 2 (2019): 147-56.

Setiawan, Ahmad Budi. "Pengembangan Kebijakan Terhadap Penyediaan Layanan Aplikasi Dan Konten Pada Ekosistem Digital Melalui Over The Top." Jurnal Penelitian Pos Dan Informatika 8, no. 2 (2018): 169-84. https://doi.org/10.17933/jppi.2018.080206.

Suran Ningsih, Ayup, and Balqis Hediyati Maharani. "Penegakan Hukum Hak Cipta Terhadap Pembajakan Film Secara Daring." Jurnal Meta Yuridis 2, no. 1 (2019): 13-32. https://doi.org/10.26877/m-y.v2i1.3440.

Taliwongso, Ronna Novy Yosia. "Perlindungan Hukum Atas Hak Kekayaan Intelektual Khususnya Merek Di Indonesia." Lex et Societatis II, no. 7 (2014): 147-58.

Utama, Arya, Titin Titawati, and Aline Febriyani Loilewen. "Perlindungan Hukum Terhadap Hak Cipta Lagu Dan Musik Menurut Undang-Undang Nomor 28 Tahun 2004." Ganec Swara 13, no. 1 (2019): 78-83. https://doi.org/10.35327/gara.v13i1.65.

Yanto, Oksidelfa. "Konsep Perlindungan Hak Cipta Dalam Ranah Hukum Hak Kekayaan Intelektual (Studi Kritis Pembajakan Karya Cipta Musik Dalam Bentuk VCD Dan DVD).” Yustisia Jurnal Hukum 93, no. 3 (2015): 746-60. https://doi.org/10.20961/yustisia.v93i0.3702. 
AJUDIKASI : Jurnal Ilmu Hukum, Volume 5 Nomor 1, Juni 2021. Hlm 1-16

P-ISSN 2613-9995 \& E-ISSN 2614-0179

\section{Peraturan Perundang-Undangan}

Undang-Undang Nomor 28 Tahun 2014 tentang Hak Cipta.

Undang-Undang Nomor 11 Tahun 2008 tentang Informasi dan Transaksi Elektronik.

Undang-Undang Nomor 19 Tahun 2016 tentang Perubahan Atas Undang-Undang Nomor 11 Tahun 2008 tentang Informasi dan Transaksi Elektronik.

Peraturan Pemerintah Nomor 71 Tahun 2019 tentang Penyelenggaraan Sistem dan Transaksi Elektronik.

Surat Edaran Menteri Komunikasi dan Informatika Nomor 3 Tahun 2016 tentang Penyediaan Layanan Aplikasi dan/atau Konten Melalui Internet (Over The Top). 